\title{
Synaptic Actin Dysregulation, a Convergent Mechanism of Mental Disorders?
}

\author{
Zhen Yan, ${ }^{1} \oplus^{-E u n j o o n ~ K i m, ~}{ }^{2,3}{ }^{\oplus D i b y a d e e p ~ D a t t a,}{ }^{4}{ }^{-D a v i d}$ A. Lewis, ${ }^{4}$ and Scott H. Soderling 5 \\ ${ }^{1}$ Department of Physiology and Biophysics, State University of New York at Buffalo, Buffalo, New York 14214, ${ }^{2}$ Center for Synaptic Brain Dysfunctions, \\ Institute for Basic Science, Kuseong-dong, Yuseong-ku, Daejeon 305-701, Korea, ${ }^{3}$ Department of Biological Sciences, Korea Advanced Institute of Science \\ and Technology, Kuseong-dong, Yuseong-ku, Daejeon 305-701, Korea, ${ }^{4}$ Department of Psychiatry, University of Pittsburgh, Pittsburgh, Pennsylvania \\ 15213, and ${ }^{5}$ Departments of Cell Biology and Neurobiology, Duke University Medical School, Durham, North Carolina 27710
}

Actin polymerization governs activity-dependent modulation of excitatory synapses, including their morphology and functionality. It is clear from human genetics that neuropsychiatric and neurodevelopmental disturbances are multigenetic in nature, highlighting the need to better understand the critical neural pathways associated with these disorders and how they are altered by genetic risk alleles. One such signaling pathway that is heavily implicated by candidate genes for psychiatric and neurodevelopmental disorders are regulators of signaling to the actin cytoskeleton, suggesting that its disruption and the ensuring abnormalities of spine structures and postsynaptic complexes is a commonly affected pathway in brain disorders. This review will discuss recent experimental findings that strongly support genetic evidence linking the synaptic cytoskeleton to mental disorders, such as schizophrenia and autism spectrum disorders.

Key words: actin; Arp2/3; autism; dendritic spine; NMDA receptor; schizophrenia

\section{Introduction}

Dendritic spines are the postsynaptic sites of most excitatory synaptic contacts. They are less than a femtoliter in volume, and yet they are necessary for information coding and memory storage. The underlying cytoskeleton of the spine is almost exclusively composed of a highly branched meshwork of actin filaments (Korobova and Svitkina, 2010), with $\sim 85 \%$ of the filaments constantly remodeling with an average turnover time of $44 \mathrm{~s}$ in the spine head (Star et al., 2002). Multiple lines of evidence, including imaging, biochemical, and genetic studies, demonstrate that the modulation of this underlying actin cytoskeleton is a critical driver of most of the essential functions of the spine, including their development (Sala and Segal, 2014) trans-synaptic adhesion (Spence and Soderling, 2015), receptor anchoring and trafficking (Allison et al., 1998; Glebov et al., 2015; Loebrich et al., 2016), and structural plasticity during LTP and LTD (Dillon and Goda, 2005).

Consistent with the central role of actin remodeling in governing most spine functions, dysfunction of the signaling pathways that reorganize synaptic actin is associated with a diverse range of developmental brain disorders, including autism spec-

\footnotetext{
Received July 26, 2016; revised Aug. 30, 2016; accepted Sept. 1, 2016.

This work was supported by Nancy Lurie Marks Family Foundation to Z.Y., and National Institutes of Health Grants MH103374 to S.H.S., NS059957 to S.H.S., MH043784 to D.A.L., MH103204 to D.A.L., DA037618 to Z.Y., MH108842 to Z.Y., and Institute for Basic Science R002-D1 to E.K.

D.A.L. currently receives investigator-initiated research support from Pfizer and in 2014-2016 served as a consultant in the areas of target identification and validation and new compound development to Autifony, BristolMyers Squibb, Concert Pharmaceuticals, and Sunovion. The remaining authors declare no competing financial interests.

Correspondence should be addressed to Dr. Scott H. Soderling, Departments of Cell Biology and Neurobiology, Duke University Medical School, Durham, NC 27710. E-mail: scott.soderling@duke.edu.

DOI:10.1523/JNEUROSCI.2360-16.2016

Copyright $\odot 2016$ the authors $\quad 0270-6474 / 16 / 3611411-07 \$ 15.00 / 0$
}

trum disorders (ASDs), schizophrenia, and intellectual disability. Indeed, human risk alleles for these disorders in genes, such as SHANK3, GIT1, DISC1, SRGAP3, OPHN1, LIMK1, NRG1, CYFIP1, SYNGAP1, KALRN, NCKAP1, and CNKSR2, regulate the upstream signaling events that induce actin cytoskeletal dynamics in dendritic spines (Meng et al., 2002; Govek et al., 2004; Gu et al., 2005; Hayashi-Takagi et al., 2010; Carlson et al., 2011; Won et al., 2011; Durand et al., 2012; De Rubeis et al., 2013; Han et al., 2013; Sanders et al., 2015). Moreover, features of neurons regulated by actin, such as spine density and morphology, are often abnormal in subjects with developmental brain disorders (Williams et al., 1980; Hutsler and Zhang, 2010). In this review, we cover recent studies in model organisms, such as mouse, as well as in postmortem human brain samples, that investigated how perturbations in actin intersect with synaptic, circuit, and behavioral phenotypes relevant to these disorders.

Synaptic cytoskeletal disturbances that drive abnormal wiring and behavior

The architecture of the actin cytoskeleton within the postsynaptic spine is predominately branched actin filaments that are formed by the Actin-related protein-2/3 (Arp2/3) complex (Korobova and Svitkina, 2010). The Arp $2 / 3$ activator, WAVE1, is present within spines, and Arp $2 / 3$ is specifically enriched within a submembrane region (20-100 $\mathrm{nm}$ from the membrane) surrounding the spine head (Soderling et al., 2007; Rácz and Weinberg, 2008). Several lines of evidence support a possible role for dysregulation of signaling upstream of Arp2/3 in developmental brain disorders. For instance, one function of DISC1, a susceptibility gene for schizophrenia, is to regulate Rac signaling to spine actin via the guanine nucleotide exchange factor Kalirin-7 (Hayashi-Takagi et al., 2010). Additionally, postmortem analysis reveals decreased expression of proteins that 
regulate synaptic actin signaling, including the Rho-family GTPases (Hill et al., 2006; Hayashi-Takagi et al., 2010). Another schizophrenia-linked gene, DTNBP1, encodes the protein disbindin-1, which assembles a protein complex with Abil and WAVE family members that may be important for maintaining normal spine morphology (Ito et al., 2010). Copy number variants associated with schizophrenia also impact key cytoskeletal signaling molecules, including CYFIP1 and WRP/srGAP3, which regulate Rac-to-WAVE signal transduction (Soderling et al., 2002; Stefansson et al., 2008; Addington and Rapoport, 2009; Zhao et al., 2013). More recently, the gene encoding the WAVE1 regulatory protein, NckAp1, has been identified as a strong risk allele for autism (Sanders et al., 2015). Recent work by the Lewis laboratory (see below) has also shown that the expression of subunits of the Arp2/3 Complex is significantly downregulated in the prefrontal cortex (PFC) from individuals with schizophrenia (Datta et al., 2016).

The hypothesis that disrupted regulation of Arp2/3 activity can underlie the synaptic and behavioral phenotypes associated with these developmental brain disorders has recently been tested $\mathrm{IH}$ Kim et al., 2013). Loss of Arp2/3 activity in cortical pyramidal neurons resulted in an immediate impairment of LTP-induced spine structural plasticity and induced a progressive loss of spines in vivo. The time course of these synaptic deficits overlapped with the development of multiple positive, negative, and cognitive-type behavioral symptoms that were consistent with a schizophrenia-like model. In a follow-up study (IH Kim et al., 2015), it was found the positive-like symptoms responded to antipsychotics (haloperidol) and were demonstrated to be due to the loss of Arp2/3 activity in the PFC. Interestingly, pyramidal neurons of the PFC that had lost ArpC3 became more excitable as spines were lost, and they projected to the dopamine-producing neurons of the ventral tegmental area/substantia nigra pars compacta. The resulting circuit abnormality resulted in elevated striatal dopamine levels, which may explain the efficacy of haloperidol in this model.

Although these studies have examined the role of Arp2/3 in maintaining dendritic spines of mature neurons, it is also likely to be important during the early development of excitatory synapses. This developmental wiring of neuronal networks involves the initiation of spine formation (dendritic filopodial emergence) and spine maturation (spine head enlargement and subsequent AMPA-type glutamate receptor recruitment or synapse "unsilencing"). The role of dendritic filopodia in spinogenesis is supported by several lines of evidence. Specifically, filopodia initiate contacts with synaptic partners (Jontes and Smith, 2000; Yuste and Bonhoeffer, 2004) to create a synapse (Fiala et al., 1998; Harris, 1999) and that dendritic filopodia select appropriate axons with which to form connections (Lohmann and Bonhoeffer, 2008).

Most filopodial structures are composed of bundled linear parallel actin filaments (Svitkina et al., 2003); however, recent electron microscopy imaging suggests that dendritic filopodia are composed of branched filaments of mixed polarity, implying that the actin structure of dendritic filopodia is unique and requires Arp2/3 activity to form (Korobova and Svitkina, 2010). In contrast to this, $\mathrm{mDia} 2$, an actin nucleator that promotes linear actin filaments, facilitates dendritic filopodial formation, suggesting that linear actin filaments promote nascent filopodial emergence (Hotulainen et al., 2009). Recently, the roles of Arp2/3 activity in this initial stage of excitatory synapse formation were tested (Spence et al., 2016). It was found that loss of either Rac or Arp2/3 activity promoted dendritic filopodial emergence, rather than impairing their formation. This is in line with prior data showing that dendritic filopodia exhibit unique actin regulatory proteins, such as SrGAP3/WRP, which turns off Rac activity and facilitates filopodial emergence (Soderling et al., 2002; Carlson et al., 2011). Perhaps more interestingly, dendritic protrusions that form in the absence of Arp2/3 fail to recruit AMPA-type glutamate receptors and do not undergo the developmental process of synapse unsilencing (Spence et al., 2016).

Abnormalities in synapse development and AMPAR-dependent unsilencing are likely to be relevant to neurodevelopmental disorders. For example, in mouse models of Fragile-X syndrome, there is a delay in the unsilencing of synapses in the barrel cortex (Harlow et al., 2010). In contrast, other models of ASD, such as Syngap1 mutant mice, appear to unsilence their synapses prematurely in the hippocampus (Rumbaugh et al., 2006; Clement et al., 2013). Evidence suggests that both mouse models exhibit altered regulation of the synaptic cytoskeleton (see also below) (Carlisle et al., 2008; Chen et al., 2010; Dolan et al., 2013). Thus, dysfunctional regulation of Arp2/3-dependent actin remodeling may impact not only the density of synapse formation, but also severely impact the functional connectivity of these synapses.

\section{Targeting actin regulators for mental disorders}

Upstream of Arp2/3 is the Rho GTPase family, the best studied of which are Rac1, RhoA, and Cdc42. Rac1 stimulates spine formation, dendrite initiation, elongation, and branching complexity (Threadgill et al., 1997). The major downstream effectors of Rac1 are p21-activated kinase (PAK) and LIM-domain containing protein kinase (LIMK), which facilitate actin filament assembly through the phosphorylation and inactivation of cofilin (Sells et al., 1997; Arber et al., 1998), a major actin-severing protein (Bamburg, 1999; dos Remedios et al., 2003). Abnormalities in Rho GTPase signaling have been identified as a prominent cause of intellectual disability (Allen et al., 1998; Ramakers, 2002). Regulation of the RhoA pathway in the inner cortical plate is crucial for controlling brain size and connectivity, and its dysregulation by de novo mutations is considered to confer a high risk for autism and schizophrenia (Lin et al., 2015). Emerging evidence suggests that aberrant Rac1/PAK signaling could lead to abnormal neuronal connectivity and synaptic function, as well as deficient cognitive and emotional functioning. Forebrain-specific dominant-negative PAK transgenic mice display fewer dendritic spines in cortical neurons, impaired synaptic plasticity, and specific deficits in the consolidation of long-term memory (Hayashi et al., 2004). Rac/PAK signaling is also defective in Fragile-X syndrome, the most common form of inherited intellectual disability (Chen et al., 2010). Administration of a PAK inhibitor rescues Fragile-X syndrome phenotypes, such as seizures, hyperactivity, and repetitive movements (Dolan et al., 2013). In the NAc of mice after chronic social defeat stress and human subjects with depression, Racl transcription is found to be reduced, which is associated with a repressive chromatin state surrounding Racl promoter (Golden et al., 2013).

ASDs are characterized by social deficits and repetitive behaviors, and are accompanied by several comorbidities, including intellectual disability, anxiety, hyperactivity, and epilepsy. Genetic analysis of autistic patients suggests that autism-associated de novo variants converge on the genes involved in the regulation of actin filaments and the formation and function of synapses (Gilman et al., 2011). Haploinsufficiency of Shank3 gene, which encodes a synaptic scaffolding protein at glutamatergic synapses (Naisbitt et al., 1999; Sheng and Kim, 2000; Hayashi et al., 2009), is one of the most prevalent and highly penetrant monogenic causes of autism (Bonaglia et al., 2001; Durand et al., 2007; Sebat 
et al., 2007; Betancur and Buxbaum, 2013). Mice with Shank3 deletions or mutations exhibit ASD-like behaviors and synaptic deficits (Jiang and Ehlers, 2013; Duffney et al., 2015; Bidinosti et al., 2016; Zhou et al., 2016). Shank forms a complex with $\beta$ PIX, the guanine nucleotide exchange factor involved in Racl activation (Manser et al., 1998), and overexpression of Shank in cultured neurons promotes synaptic accumulation of $\beta$ PIX (Park et al., 2003). A recent study (Duffney et al., 2015) has found that the expression of $\beta$ PIX is strongly reduced in the PFC of Shank3deficient mice, which leads to the decreased Racl activity. The Racl downstream effectors, active PAK and LIMK, are also significantly reduced in Shank3-deficient mice, which results in the disinhibition of cofilin. Consequently, the level of F-actin is substantially decreased in PFC of Shank3-deficient mice. In corroboration with these results, overexpression of Shank3 has been found to enhance actin polymerization by interacting with the Arp2/3 complex (Durand et al., 2012) and increase F-actin levels (Han et al., 2013).

These observations lead to the hypothesis that dysregulation of the synaptic actin cytoskeleton is an important component of the pathology that drives autistic phenotypes in Shank3-deficient mice. Interestingly, inhibition of cofilin activity produces a robust rescue of the social preference deficits and repetitive behavior in Shank3-deficient mice, which correlates well with the restoration of NMDAR trafficking and function, suggesting a promising therapeutic strategy for autism treatment (Duffney et al., 2015). Inhibiting PAK or Racl function in wild-type animals produces ASD-like social deficits and NMDAR hypofunction, whereas elevating Rac1 activity in PFC of Shank3-deficient mice leads to the rescue of behavioral and NMDAR abnormality, confirming the importance of Rac1/PAK signaling in autism (Duffney et al., 2015). These lines of evidence have revealed actin dysregulation and ensuing NMDAR hypofunction in PFC pyramidal neurons as a pathophysiological basis for the ASD-like behaviors in a Shank3 model of autism. It also suggests that perturbing the signaling molecules in Rac1/PAK/cofilin pathway to normalize cortical actin dynamics offers a potential therapeutic strategy to ameliorate cognitive and synaptic defects in autism. Nonspecific effects generated by actin-manipulating agents are potentially a concern; however, many actin regulators are largely brain-specific and more likely to represent appropriate future targets. For example, high-throughput gene expression profiling has found that different actin interacting proteins have distinct transcriptional activity in different brain regions and non-CNS areas, thus targeting the actin regulators highly restricted to frontal cortex, such as human PAK3, whose mutation causes X-linked mental retardation (Allen et al., 1998), could enable the specific normalization of actin dynamics at PFC glutamatergic synapses. Moreover, different postsynaptic proteins are differentially affected by altered actin dynamics. As discussed below, Shank3 directly links NMDARs to actin cytoskeleton, making NMDARs particularly sensitive to Shank3-induced changes in actin dynamics.

\section{Actin abnormalities, NMDA receptor dysfunction, and autism spectrum disorders}

Dysfunction of NMDARs has recently been proposed as a candidate mechanism for ASDs, based on the results from animal models of this disorder. Interestingly, animal models of ASDrelated phenotypes can display altered (reduced or enhanced) NMDAR function and these autistic-like behaviors are often normalized by pharmacological modulation of NMDARs (Lee et al., 2015a). Although it is clear that multiple mechanisms could lead to altered NMDAR levels, the synaptic actin cytoskeleton is known to be important for the synaptic retention of NMDARs under basal conditions and during synaptic activity (Rosenmund and Westbrook, 1993; Allison et al., 1998; Morishita et al., 2005), and its dysregulation is likely involved in NMDAR dysfunction.

Multiple examples of reduced NMDAR function associated with ASD-like behaviors have recently been described. For instance, mice lacking the postsynaptic adhesion molecule neuroligin-1 show repetitive self-grooming associated with reduced NMDAR function, which is rescued by treatment of the mice with the NMDAR agonist D-cycloserine to enhance NMDAR function (Blundell et al., 2010). In addition, mice lacking the excitatory postsynaptic scaffolding protein Shank2 have been shown to display autistic-like social deficits that are responsive to D-cycloserine (Won et al., 2012).

Shank family proteins associate with diverse synaptic proteins, including the actin-binding/regulatory proteins cortactin (Du et al., 1998), Arp2/3 (Han et al., 2013), Abp1 (Qualmann et al., 2004; Haeckel et al., 2008), $\beta$ PIX, and IRSp53 (Bockmann et al., 2002; Soltau et al., 2002; Soltau et al., 2004). These results suggest the strong possibility that deletion of Shank genes in mice may decrease synaptic actin filaments, leading to a suppression of the synaptic localization of NMDARs. Recently, four different mouse lines lacking Shank3 have been shown to exhibit reduced NMDAR function and autistic-like behaviors, strongly suggesting that this is a core pathology of these models (Kouser et al., 2013; Duffney et al., 2015; Jaramillo et al., 2015; Speed et al., 2015). Importantly, cofilin inhibition or Racl activation, which could enhance synaptic F-actin levels, has been shown to normalize both the reduced NMDAR function and autistic-like behaviors in a line of Shank3-mutant mice (Duffney et al., 2015).

Interestingly, excessive NMDAR function may also lead to autistic-like phenotypes. For example, mice and rats prenatally exposed to valproic acid, an antiepileptic agent, display enhanced NMDAR function and autistic-like behaviors (in the case of rats) (Rinaldi et al., 2007), which are rescued by the NMDAR antagonist memantine (KC Kim et al., 2014; Kang and Kim, 2015). Most recently, memantine also rescued repetitive behaviors of mice lacking astroglial glutamate transporter, supporting the notion that excessive NMDAR activity is also associated with autistic-like behaviors (Aida et al., 2015). In some cases, this enhanced NMDAR activity may be linked to altered regulation of the actin cytoskeleton. For example, autistic-like social deficits are observed in mice lacking the excitatory postsynaptic scaffolding protein IRSp53, and an unusually stable synaptic actin cytoskeleton may underlie these phenotypes (MH Kim et al., 2009). IRSp53-mutant mice have abnormally stabilized actin filaments in the hippocampus that are resistant to cofilin activation (Chung et al., 2015). This is thought to increase synaptic content of NMDARs under basal conditions and suppress activitydependent removal of synaptic NMDARs during long-term depression of NMDAR-mediated currents, a process known to require actin depolymerization (Morishita et al., 2005). Memantine, which rescues the social deficits in IRSp53-mutant mice, also normalizes the reduced long-term depression of NMDAR-mediated currents (Chung et al., 2015). These results, together with the D-cycloserine results and studies of Shank3 mutant mice, suggest that NMDAR dysfunction in either direction can cause autistic-like behaviors in animals.

A challenge going forward will be to determine whether a significant portion of the NMDAR dysfunctions observed in animal models of ASDs involves actin dysfunction, as it is clear other mechanisms also lead to NMDAR disturbances. For instance, the transcription factor Tbr1 regulates the expression of the gene encoding the GluN2B subunits of NMDARs (Wang et al., 2004a, b). Therefore, the reduced NMDAR function observed 
in the amygdala of Tbr1-mutant mice (Chuang et al., 2014; Huang et al., 2014; Lee et al., 2015b) is likely to be caused by insufficient levels of GluN2B-containing NMDARs. However, in principle, any proteins that can impact synaptic actin filaments have the potential to be associated with NMDAR dysfunction and autistic-like behaviors in animals. Given that synaptic retention of AMPA receptors also requires intact actin filaments (Allison et al., 1998), defects in actin-binding/regulator proteins may also affect AMPAR-mediated synaptic transmission at excitatory synapses through direct mechanisms or indirectly through modulation of NMDARs. These changes at excitatory synapses may lead to the alteration of the balance between excitatory and inhibitory synapses in a neuron and disruption of neural circuits in the brains of animal models of ASD.

\section{Altered regulation of actin dynamics and cortical dendritic spine deficits in schizophrenia}

In schizophrenia, deficits in cognitive functions are core and clinically critical features of the illness (Elvevåg and Goldberg, 2000). These deficits include working memory impairments, which appear to reflect alterations in specific elements of dorsolateral prefrontal cortex (DLPFC) circuitry that are known to be critical for working memory in primates (Arnsten et al., 2012). For example, reciprocal excitatory connections among DLPFC layer 3 pyramidal cells are thought to mediate sustained neuronal activity during the maintenance phase of working memory tasks in monkeys (Goldman-Rakic, 1995). These connections terminate on dendritic spines; thus, dendritic spine density can serve as a proxy for the number of excitatory inputs that a pyramidal neuron receives (Glausier and Lewis, 2013).

Basilar dendritic spine density has been consistently found to be lower on layer 3 pyramidal cells of the DLPFC (Garey et al., 1998; Glantz and Lewis, 2000; Konopaske et al., 2014) and at least some other cortical regions (Sweet et al., 2009) in subjects with schizophrenia. In contrast, spine density does not appear to be altered on pyramidal neurons in layers 5 or 6 of the DLPFC (Kolluri et al., 2005). These findings have raised the following questions: (1) What pathogenic process might account for lower dendritic spine density in the illness? (2) What molecular mechanisms could explain the presence of spine deficits preferentially on layer 3 pyramidal neurons? (3) Could these mechanisms, and the resulting spine deficits, give rise not only to working memory impairments but also to the psychotic features that are characteristic of schizophrenia?

Convergent lines of evidence suggest that the pathogenic process underlying cortical dendritic spine deficits in schizophrenia involves altered regulation of the actin cytoskeleton required for the formation and maintenance of spines. First, de novo mutations in schizophrenia are over-represented among loci encoding cytoskeleton-associated proteins that regulate actin (Fromer et al., 2014). Second, key molecules that regulate actin dynamics exhibit altered expression in the DLPFC of subjects with schizophrenia. For example, Rho GTPase cell division cycle 42 (Cdc42) regulates the actin polymerization required for spine maturation (Scott et al., 2003; Saneyoshi et al., 2010); Cdc42 mRNA levels are lower in the DLPFC of subjects with schizophrenia (Hill et al., 2006), including in layer 3 pyramidal neurons (Datta et al., 2015). Similarly, transcript levels of kalirin, a Rho-family guanine exchange factor that is highly concentrated in spines and regulates spine integrity through Rac signaling pathways (Cahill et al., 2009), are lower in the DLPFC of subjects with schizophrenia (Hill et al., 2006). Finally, expression levels of multiple subunits of the Arp2/3 complex are altered in pyramidal neurons, but not in other cell types, in DLPFC layer 3 from subjects with schizophrenia (Datta et al., 2016). These findings suggest that the synaptic actin cytoskeleton is impaired in schizophrenia, potentially contributing to decreased spine stability and ultimately spine loss.

It is important to note that at least some of these gene expression alterations are present in layer 5 pyramidal neurons that do not exhibit spine deficits in schizophrenia, and that the levels of these transcripts predict spine density only in pyramidal cells in layer 3 (Hill et al., 2006) (Ide and Lewis, 2010). However, the presence of these alterations in pyramidal cells in both layers suggests that these deficits (1) are not a secondary consequence of a lower number of dendritic spines, and (2) might be a necessary but not a sufficient cause of reduced spine density.

The apparent specificity of the spine deficits to layer 3 pyramidal neurons might reflect disturbances in molecules that are expressed selectively in these neurons. For example, several members of the Cdc42 effector protein family (Cdc42ep3 and Cdc42ep4), which are inhibited by Cdc42 activity, are preferentially expressed in layers 2 and 3 of the DLPFC (Arion et al., 2007). In schizophrenia, expression levels of CDC42EP3 and CDC42EP4 are upregulated in layer 3 pyramidal cells (Ide and Lewis, 2010; Datta et al., 2015). Signaling via the Cdc42-CDC42EP complex regulates septin organization, which can act as a barrier in the spine neck that controls the flow of molecules into spines required for F-actin-mediated growth of spines and synaptic potentiation (Joberty et al., 2001; Ewers et al., 2014). The combination of lower levels of Cdc42 and higher levels of CDC42EPs in schizophrenia might alter the septin filament barrier, impair spine plasticity, and result in spine loss (Ide and Lewis, 2010). In addition, recent gene expression studies specifically in DLPFC layer 3 pyramidal cells suggest that dysfunction in the Cdc42- PAK- LIMK signaling pathway could also alter actin dynamics (Datta et al., 2015). Thus, the prominence of spine deficits in layer 3 pyramidal cells in schizophrenia might reflect the convergent effects of alterations in different actin pathways, each of which could destabilize the synaptic actin cytoskeleton.

Altered network activity in DLPFC layer 3 could contribute to the working memory impairments present in schizophrenia (Gonzalez-Burgos et al., 2015) and was also hypothesized (Weinberger, 1987) to cause the excessive dopamine release in the associative striatum associated with the psychotic symptoms of the illness (Howes et al., 2012). Evidence for causality in this association was recently provided by findings that deletion of the Arp2/3 complex in mice resulted in cortical spine deficits and a subcortical hyperdopaminergia that improved with antipsychotic medications (IH Kim et al., 2015). Thus, the pathogenic processes and molecular mechanisms producing cell typespecific alterations in actin dynamics could produce cortical dendritic spine deficits as an upstream pathology that subsequently gives rise to excessive striatal dopamine function and the appearance of psychosis in schizophrenia (Lewis and Gonzalez-Burgos, 2006).

\section{Conclusion and future directions}

It is becoming clear from human genetic and brain tissue studies, and from mouse models, that dysfunction of the actin cytoskeleton at excitatory spine synapses is likely a shared molecular pathology across different neurodevelopmental and psychiatric disorders. This realization, however, opens many new avenues for future work that will be required to address critical and complicated questions raised by these findings. First, a better understanding of specific actin-dependent spine functions that are disrupted at different developmental stages and in different brain 
regions is clearly needed to better define the molecular mechanisms of these disorders. As human genetic analyses continue to identify new risk alleles, there will also be an increasing need for new animal models to define these mechanisms. Where possible, it will be essential to corroborate findings from animal models with the analysis of clinical samples. Second, a better understanding of how specific mutations of the synaptic actin pathway may result in clinically diverse disorders is needed. The recent focus on Research Domains of Criteria may be beneficial in terms of focusing on behavioral and circuit phenotypes that cross current diagnostic boundaries (Insel et al., 2010). Finally, it is clear that neuronal actin remodeling is critical at other synaptic sites within neurons, including presynaptic terminals and inhibitory synapses. How these may be impacted in the context of disorders whose basis is dysfunctional actin remodeling will be an important future direction.

\section{References}

Addington AM, Rapoport JL (2009) The genetics of childhood-onset schizophrenia: when madness strikes the prepubescent. Curr Psychiatry Rep 11:156-161. CrossRef Medline

Aida T, Yoshida J, Nomura M, Tanimura A, Iino Y, Soma M, Bai N, Ito Y, Cui W, Aizawa H, Yanagisawa M, Nagai T, Takata N, Tanaka KF, Takayanagi R, Kano M, Götz M, Hirase H, Tanaka K (2015) Astroglial glutamate transporter deficiency increases synaptic excitability and leads to pathological repetitive behaviors in mice. Neuropsychopharmacology 40: 1569-1579. CrossRef Medline

Allen KM, Gleeson JG, Bagrodia S, Partington MW, MacMillan JC, Cerione RA, Mulley JC, Walsh CA (1998) PAK3 mutation in nonsyndromic X-linked mental retardation. Nat Genet 20:25-30. CrossRef Medline

Allison DW, Gelfand VI, Spector I, Craig AM (1998) Role of actin in anchoring postsynaptic receptors in cultured hippocampal neurons: differential attachment of NMDA versus AMPA receptors. J Neurosci 18: 2423-2436. Medline

Arber S, Barbayannis FA, Hanser H, Schneider C, Stanyon CA, Bernard O, Caroni P (1998) Regulation of actin dynamics through phosphorylation of cofilin by LIM-kinase. Nature 393:805-809. CrossRef Medline

Arion D, Unger T, Lewis DA, Mirnics K (2007) Molecular markers distinguishing supragranular and infragranular layers in the human prefrontal cortex. Eur J Neurosci 25:1843-1854. CrossRef Medline

Arnsten AF, Wang MJ, Paspalas CD (2012) Neuromodulation of thought: flexibilities and vulnerabilities in prefrontal cortical network synapses. Neuron 76:223-239. CrossRef Medline

Bamburg JR (1999) Proteins of the ADF/cofilin family: essential regulators of actin dynamics. Annu Rev Cell Dev Biol 15:185-230. CrossRef Medline

Betancur C, Buxbaum JD (2013) SHANK3 haploinsufficiency: a "common" but underdiagnosed highly penetrant monogenic cause of autism spectrum disorders. Mol Autism 4:17. CrossRef Medline

Bidinosti M, Botta P, Krüttner S, Proenca CC, Stoehr N, Bernhard M, Fruh I, Mueller M, Bonenfant D, Voshol H, Carbone W, Neal SJ, McTighe SM, Roma G, Dolmetsch RE, Porter JA, Caroni P, Bouwmeester T, Lüthi A, Galimberti I (2016) CLK2 inhibition ameliorates autistic features associated with SHANK3 deficiency. Science 351:1199-1203. CrossRef Medline

Blundell J, Blaiss CA, Etherton MR, Espinosa F, Tabuchi K, Walz C, Bolliger MF, Südhof TC, Powell CM (2010) Neuroligin-1 deletion results in impaired spatial memory and increased repetitive behavior. J Neurosci 30: 2115-2129. CrossRef Medline

Bockmann J, Kreutz MR, Gundelfinger ED, Böckers TM (2002) ProSAP/ Shank postsynaptic density proteins interact with insulin receptor tyrosine kinase substrate IRSp53. J Neurochem 83:1013-1017. CrossRef Medline

Bonaglia MC, Giorda R, Borgatti R, Felisari G, Gagliardi C, Selicorni A, Zuffardi O (2001) Disruption of the ProSAP2 gene in a $t(12 ; 22)(\mathrm{q} 24.1$; q13.3) is associated with the 22q13.3 deletion syndrome. Am J Hum Genet 69:261-268. CrossRef Medline

Cahill ME, Xie Z, Day M, Photowala H, Barbolina MV, Miller CA, Weiss C, Radulovic J, Sweatt JD, Disterhoft JF, Surmeier DJ, Penzes P (2009) Kalirin regulates cortical spine morphogenesis and disease-related behavioral phenotypes. Proc Natl Acad Sci U S A 106:13058-13063. CrossRef Medline
Carlisle HJ, Manzerra P, Marcora E, Kennedy MB (2008) SynGAP regulates steady-state and activity-dependent phosphorylation of cofilin. J Neurosci 28:13673-13683. CrossRef Medline

Carlson BR, Lloyd KE, Kruszewski A, Kim IH, Rodriguiz RM, Heindel C, Faytell M, Dudek SM, Wetsel WC, Soderling SH (2011) WRP/srGAP3 facilitates the initiation of spine development by an inverse F-BAR domain, and its loss impairs long-term memory. J Neurosci 31:2447-2460. CrossRef Medline

Chen LY, Rex CS, Babayan AH, Kramár EA, Lynch G, Gall CM, Lauterborn JC (2010) Physiological activation of synaptic Rac $>$ PAK (p-21 activated kinase) signaling is defective in a mouse model of fragile $\mathrm{X}$ syndrome. J Neurosci 30:10977-10984. CrossRef Medline

Chuang HC, Huang TN, Hsueh YP (2014) Neuronal excitation upregulates Tbr1, a high-confidence risk gene of autism, mediating Grin2b expression in the adult brain. Front Cell Neurosci 8:280. CrossRef Medline

Chung W, Choi SY, Lee E, Park H, Kang J, Park H, Choi Y, Lee D, Park SG, Kim R, Cho YS, Choi J, Kim MH, Lee JW, Lee S, Rhim I, Jung MW, Kim D, Bae YC, Kim E (2015) Social deficits in IRSp53 mutant mice improved by NMDAR and mGluR5 suppression. Nat Neurosci 18:435-443. CrossRef Medline

Clement JP, Ozkan ED, Aceti M, Miller CA, Rumbaugh G (2013) SYNGAP1 links the maturation rate of excitatory synapses to the duration of criticalperiod synaptic plasticity. J Neurosci 33:10447-10452. CrossRef Medline

Datta D, Arion D, Corradi JP, Lewis DA (2015) Altered expression of CDC42 signaling pathway components in cortical layer 3 pyramidal cells in schizophrenia. Biol Psychiatry 78:775-785. CrossRef Medline

Datta D, Arion D, Roman KM, Volk DW, Lewis DA (2016) Altered expression of ARP2/3 complex signaling pathway genes in prefrontal layer 3 pyramidal cells in schizophrenia. Am J Psychiatry. Advance online publication. Retrieved Aug. 13, 2016. doi: appiajp201616020204. CrossRef Medline

De Rubeis S, Pasciuto E, Li KW, Fernández E, Di Marino D, Buzzi A, Ostroff LE, Klann E, Zwartkruis FJ, Komiyama NH, Grant SG, Poujol C, Choquet D, Achsel T, Posthuma D, Smit AB, Bagni C (2013) CYFIP1 coordinates mRNA translation and cytoskeleton remodeling to ensure proper dendritic spine formation. Neuron 79:1169-1182. CrossRef Medline

Dillon C, Goda Y (2005) The actin cytoskeleton: integrating form and function at the synapse. Annu Rev Neurosci 28:25-55. CrossRef Medline

Dolan BM, Duron SG, Campbell DA, Vollrath B, Shankaranarayana Rao BS, Ko HY, Lin GG, Govindarajan A, Choi SY, Tonegawa S (2013) Rescue of fragile $\mathrm{X}$ syndrome phenotypes in Fmr1 KO mice by the small-molecule PAK inhibitor FRAX486. Proc Natl Acad Sci U S A 110:5671-5676. CrossRef Medline

dos Remedios CG, Chhabra D, Kekic M, Dedova IV, Tsubakihara M, Berry DA, Nosworthy NJ (2003) Actin binding proteins: regulation of cytoskeletal microfilaments. Physiol Rev 83:433-473. CrossRef Medline

Du Y, Weed SA, Xiong WC, Marshall TD, Parsons JT (1998) Identification of a novel cortactin SH3 domain-binding protein and its localization to growth cones of cultured neurons. Mol Cell Biol 18:5838-5851. CrossRef Medline

Duffney LJ, Zhong P, Wei J, Matas E, Cheng J, Qin L, Ma K, Dietz DM, Kajiwara Y, Buxbaum JD, Yan Z (2015) Autism-like deficits in Shank3deficient mice are rescued by targeting actin regulators. Cell Rep 11:14001413. CrossRef Medline

Durand CM, Betancur C, Boeckers TM, Bockmann J, Chaste P, Fauchereau F, Nygren G, Rastam M, Gillberg IC, Anckarsäter H, Sponheim E, GoubranBotros H, Delorme R, Chabane N, Mouren-Simeoni MC, de Mas P, Bieth E, Rogé B, Héron D, Burglen L, et al. (2007) Mutations in the gene encoding the synaptic scaffolding protein SHANK3 are associated with autism spectrum disorders. Nat Genet 39:25-27. CrossRef Medline

Durand CM, Perroy J, Loll F, Perrais D, Fagni L, Bourgeron T, Montcouquiol M, Sans N (2012) SHANK3 mutations identified in autism lead to modification of dendritic spine morphology via an actin-dependent mechanism. Mol Psychiatry 17:71-84. CrossRef Medline

Elvevåg B, Goldberg TE (2000) Cognitive impairment in schizophrenia is the core of the disorder. Crit Rev Neurobiol 14:1-21. Medline

Ewers H, Tada T, Petersen JD, Rácz B, Sheng M, Choquet D (2014) A septindependent diffusion barrier at dendritic spine necks. PLoS One 9:e113916. CrossRef Medline

Fiala JC, Feinberg M, Popov V, Harris KM (1998) Synaptogenesis via dendritic filopodia in developing hippocampal area CA1. J Neurosci 18: 8900-8911. Medline 
Fromer M, Pocklington AJ, Kavanagh DH, Williams HJ, Dwyer S, Gormley P, Georgieva L, Rees E, Palta P, Ruderfer DM, Carrera N, Humphreys I, Johnson JS, Roussos P, Barker DD, Banks E, Milanova V, Grant SG, Hannon E, Rose SA, et al. (2014) De novo mutations in schizophrenia implicate synaptic networks. Nature 506:179-184. CrossRef Medline

Garey LJ, Ong WY, Patel TS, Kanani M, Davis A, Mortimer AM, Barnes TR, Hirsch SR (1998) Reduced dendritic spine density on cerebral cortical pyramidal neurons in schizophrenia. J Neurol Neurosurg Psychiatry 65: 446-453. CrossRef Medline

Gilman SR, Iossifov I, Levy D, Ronemus M, Wigler M, Vitkup D (2011) Rare de novo variants associated with autism implicate a large functional network of genes involved in formation and function of synapses. Neuron 70:898-907. CrossRef Medline

Glantz LA, Lewis DA (2000) Decreased dendritic spine density on prefrontal cortical pyramidal neurons in schizophrenia. Arch Gen Psychiatry 57:65-73. CrossRef Medline

Glausier JR, Lewis DA (2013) Dendritic spine pathology in schizophrenia. Neuroscience 251:90-107. CrossRef Medline

Glebov OO, Tigaret CM, Mellor JR, Henley JM (2015) Clathrin-independent trafficking of AMPA receptors. J Neurosci 35:4830-4836. CrossRef Medline

Golden SA, Christoffel DJ, Heshmati M, Hodes GE, Magida J, Davis K, Cahill ME, Dias C, Ribeiro E, Ables JL, Kennedy PJ, Robison AJ, GonzalezMaeso J, Neve RL, Turecki G, Ghose S, Tamminga CA, Russo SJ (2013) Epigenetic regulation of RAC1 induces synaptic remodeling in stress disorders and depression. Nat Med 19:337-344. CrossRef Medline

Goldman-Rakic PS (1995) Cellular basis of working memory. Neuron 14: 477-485. CrossRef Medline

Gonzalez-Burgos G, Cho RY, Lewis DA (2015) Alterations in cortical network oscillations and parvalbumin neurons in schizophrenia. Biol Psychiatry 77:1031-1040. CrossRef Medline

Govek EE, Newey SE, Akerman CJ, Cross JR, Van der Veken L, Van Aelst L (2004) The X-linked mental retardation protein oligophrenin-1 is required for dendritic spine morphogenesis. Nat Neurosci 7:364-372. CrossRef Medline

Gu Z, Jiang Q, Fu AK, Ip NY, Yan Z (2005) Regulation of NMDA receptors by neuregulin signaling in prefrontal cortex. J Neurosci 25:4974-4984. CrossRef Medline

Haeckel A, Ahuja R, Gundelfinger ED, Qualmann B, Kessels MM (2008) The actin-binding protein Abpl controls dendritic spine morphology and is important for spine head and synapse formation. J Neurosci 28:1003110044. CrossRef Medline

Han K, Holder JL Jr, Schaaf CP, Lu H, Chen H, Kang H, Tang J, Wu Z, Hao S, Cheung SW, Yu P, Sun H, Breman AM, Patel A, Lu HC, Zoghbi HY (2013) SHANK3 overexpression causes manic-like behaviour with unique pharmacogenetic properties. Nature 503:72-77. CrossRef Medline

Harlow EG, Till SM, Russell TA, Wijetunge LS, Kind P, Contractor A (2010) Critical period plasticity is disrupted in the barrel cortex of FMR1 knockout mice. Neuron 65:385-398. CrossRef Medline

Harris KM (1999) Structure, development, and plasticity of dendritic spines. Curr Opin Neurobiol 9:343-348. CrossRef Medline

Hayashi MK, Tang C, Verpelli C, Narayanan R, Stearns MH, Xu RM, Li H, Sala C, Hayashi Y (2009) The postsynaptic density proteins Homer and Shank form a polymeric network structure. Cell 137:159-171. CrossRef Medline

Hayashi ML, Choi SY, Rao BS, Jung HY, Lee HK, Zhang D, Chattarji S, Kirkwood A, Tonegawa S (2004) Altered cortical synaptic morphology and impaired memory consolidation in forebrain-specific dominantnegative PAK transgenic mice. Neuron 42:773-787. CrossRef Medline

Hayashi-Takagi A, Takaki M, Graziane N, Seshadri S, Murdoch H, Dunlop AJ, Makino Y, Seshadri AJ, Ishizuka K, Srivastava DP, Xie Z, Baraban JM, Houslay MD, Tomoda T, Brandon NJ, Kamiya A, Yan Z, Penzes P, Sawa A (2010) Disrupted-in-Schizophrenia 1 (DISC1) regulates spines of the glutamate synapse via Rac1. Nat Neurosci 13:327-332. CrossRef Medline

Hill JJ, Hashimoto T, Lewis DA (2006) Molecular mechanisms contributing to dendritic spine alterations in the prefrontal cortex of subjects with schizophrenia. Mol Psychiatry 11:557-566. CrossRef Medline

Hotulainen P, Llano O, Smirnov S, Tanhuanpää K, Faix J, Rivera C, Lappalainen P (2009) Defining mechanisms of actin polymerization and depolymerization during dendritic spine morphogenesis. J Cell Biol 185: 323-339. CrossRef Medline

Howes OD, Kambeitz J, Kim E, Stahl D, Slifstein M, Abi-Dargham A, Kapur S
(2012) The nature of dopamine dysfunction in schizophrenia and what this means for treatment. Arch Gen Psychiatry 69:776-786. CrossRef Medline

Huang TN, Chuang HC, Chou WH, Chen CY, Wang HF, Chou SJ, Hsueh YP (2014) Tbr1 haploinsufficiency impairs amygdalar axonal projections and results in cognitive abnormality. Nat Neurosci 17:240-247. CrossRef Medline

Hutsler JJ, Zhang H (2010) Increased dendritic spine densities on cortical projection neurons in autism spectrum disorders. Brain Res 1309:83-94. CrossRef Medline

Ide M, Lewis DA (2010) Altered cortical CDC42 signaling pathways in schizophrenia: implications for dendritic spine deficits. Biol Psychiatry 68:25-32. CrossRef Medline

Insel T, Cuthbert B, Garvey M, Heinssen R, Pine DS, Quinn K, Sanislow C, Wang P (2010) Research domain criteria (RDoC): toward a new classification framework for research on mental disorders. Am J Psychiatry 167:748-751. CrossRef Medline

Ito H, Morishita R, Shinoda T, Iwamoto I, Sudo K, Okamoto K, Nagata K (2010) Dysbindin-1, WAVE2 and Abi-1 form a complex that regulates dendritic spine formation. Mol Psychiatry 15:976-986. CrossRef Medline

Jaramillo TC, Speed HE, Xuan Z, Reimers JM, Liu S, Powell CM (2016) Altered striatal synaptic function and abnormal behaviour in Shank3 exon4-9 deletion mouse model of autism. Autism Res 9:350-375. CrossRef Medline

Jiang YH, Ehlers MD (2013) Modeling autism by SHANK gene mutations in mice. Neuron 78:8-27. CrossRef Medline

Joberty G, Perlungher RR, Sheffield PJ, Kinoshita M, Noda M, Haystead T, Macara IG (2001) Borg proteins control septin organization and are negatively regulated by Cdc42. Nat Cell Biol 3:861-866. CrossRef Medline

Jontes JD, Smith SJ (2000) Filopodia, spines, and the generation of synaptic diversity. Neuron 27:11-14. CrossRef Medline

Kang J, Kim E (2015) Suppression of NMDA receptor function in mice prenatally exposed to valproic acid improves social deficits and repetitive behaviors. Front Mol Neurosci 8:17. CrossRef Medline

Kim IH, Rácz B, Wang H, Burianek L, Weinberg R, Yasuda R, Wetsel WC, Soderling SH (2013) Disruption of Arp2/3 results in asymmetric structural plasticity of dendritic spines and progressive synaptic and behavioral abnormalities. J Neurosci 33:6081-6092. CrossRef Medline

Kim IH, Rossi MA, Aryal DK, Rácz B, Kim N, Uezu A, Wang F, Wetsel WC, Weinberg RJ, Yin H, Soderling SH (2015) Spine pruning drives antipsychotic-sensitive locomotion via circuit control of striatal dopamine. Nat Neurosci 18:883-891. CrossRef Medline

Kim KC, Lee DK, Go HS, Kim P, Choi CS, Kim JW, Jeon SJ, Song MR, Shin CY (2014) Pax6-dependent cortical glutamatergic neuronal differentiation regulates autism-like behavior in prenatally valproic acid-exposed rat offspring. Mol Neurobiol 49:512-528. CrossRef Medline

Kim MH, Choi J, Yang J, Chung W, Kim JH, Paik SK, Kim K, Han S, Won H, Bae YS, Cho SH, Seo J, Bae YC, Choi SY, Kim E (2009) Enhanced NMDA receptor-mediated synaptic transmission, enhanced long-term potentiation, and impaired learning and memory in mice lacking IRSp53. J Neurosci 29:1586-1595. CrossRef Medline

Kolluri N, Sun Z, Sampson AR, Lewis DA (2005) Lamina-specific reductions in dendritic spine density in the prefrontal cortex of subjects with schizophrenia. Am J Psychiatry 162:1200-1202. CrossRef Medline

Konopaske GT, Lange N, Coyle JT, Benes FM (2014) Prefrontal cortical dendritic spine pathology in schizophrenia and bipolar disorder. JAMA Psychiatry 71:1323-1331. CrossRef Medline

Korobova F, Svitkina T (2010) Molecular architecture of synaptic actin cytoskeleton in hippocampal neurons reveals a mechanism of dendritic spine morphogenesis. Mol Biol Cell 21:165-176. CrossRef Medline

Kouser M, Speed HE, Dewey CM, Reimers JM, Widman AJ, Gupta N, Liu S, Jaramillo TC, Bangash M, Xiao B, Worley PF, Powell CM (2013) Loss of predominant Shank3 isoforms results in hippocampus-dependent impairments in behavior and synaptic transmission. J Neurosci 33:1844818468. CrossRef Medline

Lee EJ, Choi SY, Kim E (2015a) NMDA receptor dysfunction in autism spectrum disorders. Curr Opin Pharmacol 20C:8-13. CrossRef Medline

Lee EJ, Lee H, Huang TN, Chung C, Shin W, Kim K, Koh JY, Hsueh YP, Kim E (2015b) Trans-synaptic zinc mobilization improves social interaction in two mouse models of autism through NMDAR activation. Nat Commun 6:7168. CrossRef Medline

Lewis DA, Gonzalez-Burgos G (2006) Pathophysiologically based treatment interventions in schizophrenia. Nat Med 12:1016-1022. CrossRef Medline

Lin GN, Corominas R, Lemmens I, Yang X, Tavernier J, Hill DE, Vidal M, 
Sebat J, Iakoucheva LM (2015) Spatiotemporal 16p11.2 protein network implicates cortical late mid-fetal brain development and KCTD13-Cul3-RhoA pathway in psychiatric diseases. Neuron 85:742754. CrossRef Medline

Loebrich S, Benoit MR, Konopka JA, Cottrell JR, Gibson J, Nedivi E (2016) CPG2 recruits endophilin B2 to the cytoskeleton for activitydependent endocytosis of synaptic glutamate receptors. Curr Biol 26: 296-308. CrossRef Medline

Lohmann C, Bonhoeffer T (2008) A role for local calcium signaling in rapid synaptic partner selection by dendritic filopodia. Neuron 59:253-260. CrossRef Medline

Manser E, Loo TH, Koh CG, Zhao ZS, Chen XQ, Tan L, Tan I, Leung T, Lim L (1998) PAK kinases are directly coupled to the PIX family of nucleotide exchange factors. Mol Cell 1:183-192. CrossRef Medline

Meng Y, Zhang Y, Tregoubov V, Janus C, Cruz L, Jackson M, Lu WY, MacDonald JF, Wang JY, Falls DL, Jia Z (2002) Abnormal spine morphology and enhanced LTP in LIMK-1 knockout mice. Neuron 35:121-133. CrossRef Medline

Morishita W, Marie H, Malenka RC (2005) Distinct triggering and expression mechanisms underlie LTD of AMPA and NMDA synaptic responses. Nat Neurosci 8:1043-1050. CrossRef Medline

Naisbitt S, Kim E, Tu JC, Xiao B, Sala C, Valtschanoff J, Weinberg RJ, Worley PF, Sheng M (1999) Shank, a novel family of postsynaptic density proteins that binds to the NMDA receptor/PSD-95/GKAP complex and cortactin. Neuron 23:569-582. CrossRef Medline

Park E, Na M, Choi J, Kim S, Lee JR, Yoon J, Park D, Sheng M, Kim E (2003) The Shank family of postsynaptic density proteins interacts with and promotes synaptic accumulation of the beta PIX guanine nucleotide exchange factor for Racl and Cdc42. J Biol Chem 278: 19220-19229. CrossRef Medline

Qualmann B, Boeckers TM, Jeromin M, Gundelfinger ED, Kessels MM (2004) Linkage of the actin cytoskeleton to the postsynaptic density via direct interactions of Abp1 with the ProSAP/Shank family. J Neurosci 24:2481-2495. CrossRef Medline

Rácz B, Weinberg RJ (2008) Organization of the Arp2/3 complex in hippocampal spines. J Neurosci 28:5654-5659. CrossRef Medline

Ramakers GJ (2002) Rho proteins, mental retardation and the cellular basis of cognition. Trends Neurosci 25:191-199. CrossRef Medline

Rinaldi T, Kulangara K, Antoniello K, Markram H (2007) Elevated NMDA receptor levels and enhanced postsynaptic long-term potentiation induced by prenatal exposure to valproic acid. Proc Natl Acad Sci U S A 104:13501-13506. CrossRef Medline

Rosenmund C, Westbrook GL (1993) Calcium-induced actin depolymerization reduces NMDA channel activity. Neuron 10:805-814. CrossRef Medline

Rumbaugh G, Adams JP, Kim JH, Huganir RL (2006) SynGAP regulates synaptic strength and mitogen-activated protein kinases in cultured neurons. Proc Natl Acad Sci U S A 103:4344-4351. CrossRef Medline

Sala C, Segal M (2014) Dendritic spines: the locus of structural and functional plasticity. Physiol Rev 94:141-188. CrossRef Medline

Sanders SJ, He X, Willsey AJ, Ercan-Sencicek AG, Samocha KE, Cicek AE, Murtha MT, Bal VH, Bishop SL, Dong S, Goldberg AP, Jinlu C, Keaney JF 3rd, Klei L, Mandell JD, Moreno-De-Luca D, Poultney CS, Robinson EB, Smith L, Solli-Nowlan T, et al. (2015) Insights into autism spectrum disorder genomic architecture and biology from 71 risk loci. Neuron 87:1215-1233. CrossRef Medline

Saneyoshi T, Fortin DA, Soderling TR (2010) Regulation of spine and synapse formation by activity-dependent intracellular signaling pathways. Curr Opin Neurobiol 20:108-115. CrossRef Medline

Scott EK, Reuter JE, Luo L (2003) Small GTPase Cdc42 is required for multiple aspects of dendritic morphogenesis. J Neurosci 23:3118-3123. Medline

Sebat J, Lakshmi B, Malhotra D, Troge J, Lese-Martin C, Walsh T, Yamrom B, Yoon S, Krasnitz A, Kendall J, Leotta A, Pai D, Zhang R, Lee YH, Hicks J, Spence SJ, Lee AT, Puura K, Lehtimäki T, Ledbetter D, et al. (2007) Strong association of de novo copy number mutations with autism. Science 316:445-449. CrossRef Medline

Sells MA, Knaus UG, Bagrodia S, Ambrose DM, Bokoch GM, Chernoff J (1997) Human p21-activated kinase (Pak1) regulates actin organization in mammalian cells. Curr Biol 7:202-210. CrossRef Medline

Sheng M, Kim E (2000) The Shank family of scaffold proteins. J Cell Sci 113:1851-1856. Medline
Soderling SH, Binns KL, Wayman GA, Davee SM, Ong SH, Pawson T, Scott JD (2002) The WRP component of the WAVE-1 complex attenuates Rac-mediated signalling. Nat Cell Biol 4:970-975. CrossRef Medline

Soderling SH, Guire ES, Kaech S, White J, Zhang F, Schutz K, Langeberg LK, Banker G, Raber J, Scott JD (2007) A WAVE-1 and WRP signaling complex regulates spine density, synaptic plasticity, and memory. J Neurosci 27:355-365. CrossRef Medline

Soltau M, Richter D, Kreienkamp HJ (2002) The insulin receptor substrate IRSp53 links postsynaptic shank1 to the small G-protein cdc42. Mol Cell Neurosci 21:575-583. CrossRef Medline

Soltau M, Berhörster K, Kindler S, Buck F, Richter D, Kreienkamp HJ (2004) Insulin receptor substrate of $53 \mathrm{kDa}$ links postsynaptic shank to PSD-95. J Neurochem 90:659-665. CrossRef Medline

Speed HE, Kouser M, Xuan Z, Reimers JM, Ochoa CF, Gupta N, Liu S, Powell CM (2015) Autism-associated insertion mutation (InsG) of Shank3 exon 21 causes impaired synaptic transmission and behavioral deficits. J Neurosci 35:9648-9665. CrossRef Medline

Spence EF, Soderling SH (2015) Actin out: regulation of the synaptic cytoskeleton. J Biol Chem 290:28613-28622. CrossRef Medline

Spence EF, Kanak DJ, Carlson BR, Soderling SH (2016) The Arp2/3 complex is essential for distinct stages of spine synapse maturation, including synapse unsilencing. J Neurosci 37:9696-9709.

Star EN, Kwiatkowski DJ, Murthy VN (2002) Rapid turnover of actin in dendritic spines and its regulation by activity. Nat Neurosci 5:239-246. CrossRef Medline

Stefansson H, Rujescu D, Cichon S, Pietiläinen OP, Ingason A, Steinberg S, Fossdal R, Sigurdsson E, Sigmundsson T, Buizer-Voskamp JE, Hansen T, Jakobsen KD, Muglia P, Francks C, Matthews PM, Gylfason A, Halldorsson BV, Gudbjartsson D, Thorgeirsson TE, Sigurdsson A, et al. (2008) Large recurrent microdeletions associated with schizophrenia. Nature 455:232-236. CrossRef Medline

Svitkina TM, Bulanova EA, Chaga OY, Vignjevic DM, Kojima S, Vasiliev JM, Borisy GG (2003) Mechanism of filopodia initiation by reorganization of a dendritic network. J Cell Biol 160:409-421. CrossRef Medline

Sweet RA, Henteleff RA, Zhang W, Sampson AR, Lewis DA (2009) Reduced dendritic spine density in auditory cortex of subjects with schizophrenia. Neuropsychopharmacology 34:374-389. CrossRef Medline

Threadgill R, Bobb K, Ghosh A (1997) Regulation of dendritic growth and remodeling by Rho, Rac, and Cdc42. Neuron 19:625-634. CrossRef Medline

Wang GS, Hong CJ, Yen TY, Huang HY, Ou Y, Huang TN, Jung WG, Kuo TY, Sheng M, Wang TF, Hsueh YP (2004a) Transcriptional modification by a CASK-interacting nucleosome assembly protein. Neuron 42:113-128. CrossRef Medline

Wang TF, Ding CN, Wang GS, Luo SC, Lin YL, Ruan Y, Hevner R, Rubenstein JL, Hsueh YP (2004b) Identification of Tbr-1/CASK complex target genes in neurons. J Neurochem 91:1483-1492. CrossRef Medline

Weinberger DR (1987) Implications of normal brain development for the pathogenesis of schizophrenia. Arch Gen Psychiatry 44:660-669. CrossRef Medline

Williams RS, Hauser SL, Purpura DP, DeLong GR, Swisher CN (1980) Autism and mental retardation: neuropathologic studies performed in four retarded persons with autistic behavior. Arch Neurol 37:749-753. CrossRef Medline

Won H, Mah W, Kim E, Kim JW, Hahm EK, Kim MH, Cho S, Kim J, Jang H, Cho SC, Kim BN, Shin MS, Seo J, Jeong J, Choi SY, Kim D, Kang C, Kim E (2011) GIT1 is associated with ADHD in humans and ADHD-like behaviors in mice. Nat Med 17:566-572. CrossRef Medline

Won H, Lee HR, Gee HY, Mah W, Kim JI, Lee J, Ha S, Chung C, Jung ES, Cho YS, Park SG, Lee JS, Lee K, Kim D, Bae YC, Kaang BK, Lee MG, Kim E (2012) Autistic-like social behaviour in Shank2-mutant mice improved by restoring NMDA receptor function. Nature 486:261-265. CrossRef Medline

Yuste R, Bonhoeffer T (2004) Genesis of dendritic spines: insights from ultrastructural and imaging studies. Nat Rev Neurosci 5:24-34. CrossRef Medline

Zhao Q, Li T, Zhao X, Huang K, Wang T, Li Z, Ji J, Zeng Z, Zhang Z, Li K, Feng G, St Clair D, He L, Shi Y (2013) Rare CNVs and Tag SNPs at 15q11.2 are associated with schizophrenia in the Han Chinese population. Schizophr Bull 39:712-719. CrossRef Medline

Zhou Y, Kaiser T, Monteiro P, Zhang X, Van der Goes MS, Wang D, Barak B, Zeng M, Li C, Lu C, Wells M, Amaya A, Nguyen S, Lewis M, Sanjana N, Zhou Y, Zhang M, Zhang F, Fu Z, Feng G (2016) Mice with Shank3 mutations associated with ASD and schizophrenia display both shared and distinct defects. Neuron 89:147-162. CrossRef Medline 